\title{
HOW KNOWLEDGE MANAGEMENT PROCESSES CAN CREATE AND CAPTURE VALUE FOR FIRMS?
}

\begin{abstract}
:
Knowledge has become the main competitive tool for firms. Just as knowledge is considered as the most important strategic resource, knowledge management is considered to be critical to a firm's success. Several attempts have been undertaken to identify and define the different knowledge management processes. From the literature review, four key dimensions stand out as affecting knowledge management processes: knowledge creation, knowledge transfer, knowledge storage/retrieval and knowledge application. The aim of this paper is to contribute to the knowledge management and value literature by determining the importance of the different processes of knowledge management for increasing value creation and value capture in firms. The context for the research hypotheses is the Spanish banking industry in 2010. The results support a positive relationship between knowledge management and value creation, and between value creation and value capture.
\end{abstract}

\section{Keywords:}

Competitive advantage; Knowledge creation; Knowledge transfer; Organizational memory; Knowledge use/utilization.

\section{Introduction}

Over the last few decades and in the current climate, a firm's attitude towards the customer is becoming crucial. In the complex competitive environment in which firms operate, the customer now expects superior value (Sanchez et al, 2009). More and more firms therefore see customer value as a key factor when seeking new ways to attain and maintain a competitive advantage (Woodruff, 1997; Carlucci et al, 2004; Schiuma et al, 2012).

Managers should focus on developing the internal processes that view the customer as a key component, in order to create maximum customer value. The focus of this paper is on the knowledge management (KM) processes. The primary aim of firms that manage their knowledge processes is to offer superior customer value.

Much has been written about why it is important to manage knowledge processes, but there is considerably less written about how they should be managed; that is, about the processes that are used to identify, capture, share and use knowledge in firms (Ipe, 2003; Schiuma et al, 2012). There has been also considerable discussion in the recent 
literature of the relationship between KM processes and customer value (Rezgui, 2007; Schiuma, 2009). Although Vorakulpipat \& Rezgui (2008) suggest that KM processes create value inherently, some questions still remain over this theoretical justification. Moreover, no examples in the literature examine the impact of the relationship between $\mathrm{KM}$ processes on customer value viewed from the firm's point-of-view (i.e. value creation and value capture). This study addresses the gap in the literature (Schiuma et al, 2012) by determining how important are KM processes for increasing customer value and aims to identify how KM processes influence value creation and value capture. Thus, we are going to combine in this paper, both $\mathrm{KM}$ and value literature.

The specific research question is: given that customers demand superior value, which are the $\mathrm{KM}$ processes that a firm requires in order to create this superior value and to capture the value created?

Traditionally, value research and literature have been focused on the evaluation of how firms create value for their customers. In recent years, the emphasis has been on the need to consider customers as assets (Ulaga, 2001). This idea refers to the requirement that firms should be able to capture the value created.

In short, the aim of this paper is to contribute to the KM and value literature by determining the importance of the different processes of $\mathrm{KM}$ for increasing value creation and value capture in firms. We attempt to propose and analyze the importance of each of the processes of $\mathrm{KM}$ for creating superior customer value.

The paper begins with an explanation of the theoretical context, followed by a presentation of the study model and the positing of our hypotheses. The next section contains a description of the principal aspects of the methodology and data analysis. $A$ discussion of the results and implications of the study follows and the paper concludes with the limitations of the study and possible areas of further research.

\section{Theoretical Background}

\section{KM Processes}

We are going to focus on the knowledge-based view of the firm (KBV) which is a recent approach to understand the relationship between firm processes and firm performance (Holsapple \& Wu, 2008; Kiessling et al, 2009).

The recognition of knowledge as a key resource for firms in the current business environment confirms the need for processes that facilitate individual and collective knowledge creation, transfer and leverage (McElroy, 2000; Becerra-Fernandez \& 
Sabherwal, 2001; Ipe, 2003). According to McElroy (2000), a second-generation KM implies understanding how knowledge is created and how it is shared and diffused throughout the firm instead of considering knowledge only as a mean to support business operations. Every firm should understand the importance of knowledge and of teaching knowledge skills to their employees and every employee should be encouraged to create, share, search out and use knowledge in their daily routines (Davenport \& Prusak, 1998; Firestone \& McElroy, 2003).

Several attempts have been undertaken to identify and define the different KM processes (Gold et al, 2001; Ipe, 2003; Chang Lee et al, 2005; Chen \& Huang, 2009; Denford \& Chan, 2011). A review of the processes identified as KM processes by various authors allows us to distinguish four key KM processes:

1) Knowledge creation,

2) knowledge transfer,

3) knowledge storage/retrieval, and

4) knowledge application.

Based on the review of the existing literature, we state that there are discrepancies in terms of the number and labeling of processes (Alavi \& Leidner, 2001; Schiuma et al, 2012); but, at least, we must consider the above-mentioned four key KM processes.

Knowledge creation

The process of knowledge creation refers to the accumulation of knowledge in firms (Gold et al, 2001; Jantunen, 2005; Lin \& Lee, 2005)

Since the accumulation of knowledge is a result of not only internal development of knowledge but also the assimilation of external knowledge, the absorptive capacity of the firm (Cohen \& Levinthal, 1990) is critical to its success. Therefore, we argue that absorptive capacity is closely related to the process of creating knowledge. In fact, the absorptive capacity: a) represents an important part of the firm ability to create new knowledge (Cohen \& Levinthal, 1990; Chou, 2005; Lane et al, 2006; Wales et al, 2013), b) helps firms to introduce knowledge from the outside in an effort to collect a set of changing information that will enable the development of new products/services (Newey \& Zahra, 2009), and c) gives firms a potential advantage in terms of knowledge acquisition (Jantunen, 2005; Wales et al, 2013). 
Zahra \& George (2002) distinguish between a firm's potential and realized absorptive capacity. On the one hand, potential absorptive capacity (PACAP) makes the firm receptive to acquiring and assimilating external knowledge but does not guarantee the exploitation of this knowledge. On the other hand, realized absorptive capacity (RACAP) reflects the firm's capacity to leverage the knowledge that has been absorbed.

Hence, knowledge creation in our paper refers to the absorptive capacity of firms. In this way, we define knowledge creation as 'the knowledge accumulation in the firm resulting from its ability to absorb external knowledge'.

\section{Knowledge transfer}

Knowledge transfer is basically the act of making knowledge available to others within the organization (Ipe, 2003). To make knowledge become available, it is crucial that individuals and departments are involved in the process of knowledge transfer (De Vries et al, 2006). Knowledge transfer with each other is seen as an effective way to improve the knowledge that a firm has about the competitors and the industry, and to acquire local knowledge (Gold et al, 2001).

Knowledge transfer refers to the knowledge exchange between the source and the recipient of it (Gold et al, 2001; Jantunen, 2005; Baskerville \& Dulipovici, 2006; Chou et al, 2007; Radaelli et al, 2011). To remain competitive in the market, organizational knowledge and skills must be shared within the firm (Gold et al, 2001). In this way, knowledge transfer activities are an essential component in the process of KM (Alavi \& Leidner, 2001; Gold et al, 2001; Lee \& Ahn, 2007).

\section{Knowledge storage/retrieval}

All individuals in a firm must have access to the knowledge base in order to obtain the relevant knowledge to help them in their work and decision making. However, if knowledge created for years through KM activities is not retained systematically, it cannot be beneficial for future decision-making needs (Chang Lee et al, 2005). The storage and retrieval mechanisms allow firms to quickly and easily access to knowledge (Baskerville \& Dulipovici, 2006; Chou et al, 2007). The objective is to make knowledge accessible to those who need it (Davenport \& Prusak, 1998).

We advance that knowledge storage and retrieval processes are closely related to the idea of 'organizational memory'. In fact, Walsh \& Ungson (1991) define organizational 
memory as 'the stored information from an organization's history that can be brought to bear on present decisions'.

Researchers and practitioners recognize that organizational memory is an important factor for the success of the firm operations and reactions to the changes and challenges of the environment (Nilakanta et al, 2006). As such, organizational memory is simply a collection of knowledge stored in different places in a firm.

In our paper, when we speak of knowledge storage/retrieval we refer to the organizational memory. Hence, we define knowledge storage/retrieval as 'the retention of stored information from an organization's history and its quick and easy access in order to be applied on present decisions'.

\section{Knowledge application}

There is not a lot written in the literature regarding the application of knowledge. According to Gold et al (2001), knowledge application seems to be assumed by authors since it does not appear explicitly in the literature.

Several authors (Gold et al, 2001) do not make a distinction between the process of knowledge application and the process of knowledge storage/retrieval. We are going to consider them separately (Alavi \& Leidner, 2001) due to its importance for an effective $\mathrm{KM}$. Thus, we refer to knowledge application as the actual use of knowledge in the firm (Ipe, 2003; Jantunen, 2005).

One of the most common ways to use knowledge is to adopt the best practices of a leader firm, to find the relevant knowledge and to apply it (Firestone \& McElroy, 2003; Chang Lee et al, 2005). The application of knowledge implies the use of the knowledge generated in the phase of knowledge creation and retained in the phases of transfer and storage/retrieval. Therefore, knowledge application entails the internalization of knowledge in a firm. For example, when information about customers and suppliers is assimilated by decision makers in a firm and it changes their mental models about market environment.

\section{Value Creation and Capture}

After a review of the existing literature, the importance of value for a firm's success is proved (Carlucci et al, 2004; Marr et al, 2004; Sanchez \& Iniesta, 2006; Wiig, 2007; Carlucci, 2012). 
Practitioners have long since recognized that the essential elements of a firm's business strategy consist of being able to understand what customers value within a particular offering, creating value for them, and then managing this value over time (Slater \& Narver, 1998). Being able to identify what customers want from a product or service also helps a firm to formulate its value proposition.

Understanding customer value from the perspective of the value of the customer to the firm has also received attention from researchers (Payne \& Holt, 2001; Mckenzie, 2008). This stream of research focuses on the value of the customer to the firm; considering it as an output, rather than an input, of value creation. As such, it focuses not on the creation of value for the customer but on the value outcome that can be derived from delivering superior customer value. According to Payne \& Holt (2001), a key concept that forms part of this perspective is that of "customer lifetime value". This perspective views customer value as the value that a firm can obtain from its customers (Woodall, 2003) and does not consider the value provided by the firm to its customers. From an analysis of Payne \& Holt's (2001) description of this customer value perspective, we would venture that this refers to firm value capture.

Superior performance results from providing superior customer value; it is not an end in itself (Slater, 1997). Two processes, which combine and interact, are fundamental to achieving this outcome (Mizik \& Jacobson, 2003); and we focus on this two processes in this paper. One of the processes involves the creation of customer value; the other focuses on capturing value in the marketplace. The marketing concept identifies the customer as the main focus and the force that defines the scope and purpose of a firm. Value creation alone, however, is insufficient to achieve success in the marketplace; a firm's ability to restrict competitive forces (e.g. erect barriers to imitation) to enable it to capture some of the value that it has created in the form of profit, is also necessary (Mizik \& Jacobson, 2003; Mckenzie, 2008).

Therefore, due to increasing turbulence in the environment and constant changes in the current economic and competitive situations, some authors (Venkataraman \& Sarasvathy, 2001; Nonaka \& Toyama, 2002; Käpylä et al, 2011) have recently stressed that for a strategy to be effective it should foster both value creation and value capture.

\section{Conceptual Model}

The existing literature discusses the relationship between KM processes and customer value (Gebert et al, 2003). In fact, many authors describe KM as a bundle of processes that firms need to enable them to use what they know in order to create value for their 
customers (Vorakulpipat \& Rezgui, 2008). According to Schiuma et al (2012), the effectiveness of efforts of managing knowledge processes depends on the alignment of these processes with the firm's processes while supporting firm's value proposition.

In order to assess the importance of each $\mathrm{KM}$ process in $\mathrm{KM}$, we have stated the four key KM processes as formative components of KM (see Figure 1) because our paper's aim is analyzing the importance of processes of KM in the firm's value cycle (creationcapture).

\section{Insert Figure 1 about here}

Firms must focus on knowledge creation (KC). It is important for firms to develop an 'absorptive capacity' because it refers to the ability to use prior knowledge to recognize the value of new information, assimilate it and apply it to create new knowledge and capabilities (Cohen \& Levinthal, 1990). That is, KM requires the acquisition and assimilation of external knowledge (i.e. PACAP). Once knowledge is acquired and assimilated, the next step must be the transformation and exploitation of this knowledge; that is, firms need to leverage the knowledge that has been absorbed (i.e. RACAP).

Firms also must focus on knowledge transfer (KT) and knowledge storage/retrieval (KSR). These two processes are related to the retention of knowledge. We posit knowledge transfer as an implicit way of knowledge retention. What the firm knows is going to be available for people throughout the firm and is going to be stored in people minds. Regarding knowledge storage/retrieval, we posit this other process as a way of storing knowledge itself.

And finally, firms must be able to actual use what they know in order to increase the value created for customers $(K A)$.

In summary, a firm with these KM processes possesses key elements for the creation of customer value.

We therefore propose the following hypothesis:

$\mathrm{H} 1$ : KM processes influence positively on value creation of the firm.

If a firm creates value, the next step must be the capture of the value it has created. Just as when the firm creates value, it needs to have -or if not, to develop- a set of capabilities, such as barriers to imitation, in order to capture the value created. 
Value creation alone is insufficient to achieve competitive advantage and financial success and therefore, firms without the ability to restrict competitive forces (e.g. erect barriers to imitation) are unable to capture the value that they have created (Teece et al, 1997).

Mizik \& Jacobson (2003) stress that value creation investment decisions cannot be divorced from those related to value capture, since countless examples exist of innovations that created enormous value, but where the innovating firm was unable to capture the surplus. According to these authors, firms that fail to pay sufficient attention to value capture cannot be expected to achieve sustained competitive advantage and capture the benefits from their value creation capabilities.

We therefore propose the following hypothesis:

$\mathrm{H} 2$ : Value creation has a positive influence in value capture.

\section{Methodology}

Data Collection

The context for our research hypotheses (1 and 2) is the Spanish banking industry, including retail and commercial banks and savings banks that serve the general public, representing around $18 \%$ of the national GDP in 2010.

This industry sector is suitable because banking demonstrates KM capabilities. Banking is a very knowledge-intensive industry and therefore an appropriate one in which to identify, analyze and evaluate the different KM processes. The increasingly intense competition within this industry is forcing banks to recognize the need to seek new ways of creating customer value. In addition to the competitiveness of the industry, the relative intangibility of their products/services creates the need to capture and retain customers by offering them something extra (i.e. KM).

The crisis in the financial services industry is highly significant (both now and at the time the study took place). The effect of this crisis has been to force many countries to apply severe measures to reduce the impact on their financial services industry. Numerous banks and insurance company takeovers and capitalizations have taken place, the number of company mergers as a rescue measure has multiplied and crashes have increased. The full extent of this crisis is still unknown, since events have occurred at an unusually high speed, leading to enormous changes within a short time span, mainly following the crash of Lehman Brothers in September 2008. The total number of banks operating in Spain at the time of the study (i.e. 2010) was 110; of 
which 65 were commercial/retail banks and 45 were savings banks. The small number of players making up the banking industry in Spain could be an advantage as the study can examine the whole population instead of a particular sample.

Only 85 of the banks met the requirements of the study (i.e. banks serving the general public). Therefore, the target group consists of 85 financial bodies, representing around $77 \%$ of the total.

The response rate was high, at around $90 \%$, with 76 of the 85 banks completing the questionnaire by personal interview to the general manager in the main branch office. Of note is that all of the completed questionnaires are valid. Furthermore, because the data sample (76) is very close to the real population in Spanish banking industry (85), we used the factor correction suggested by Malhotra \& Birks (2006) to adapt the standard error generated.

To measure value capture, we opted to use secondary data (financial reports) because we believe that this variable should be measured objectively.

We decided to combine these sets of data (from banks and financial reports) to test the hypotheses in our theoretical model.

\section{Measures}

We opt for an absorptive capacity scale proposed by Jansen et al (2005) to measure knowledge creation, which adds to the conceptual richness of the study. This scale consists of 9 items to measure PACAP and 12 items to measure RACAP (see Appendix 1). The final cleaned scale consists of 17 items for the knowledge creation $(\mathrm{KC})$ process.

The model uses Gold et als (2001) scales to measure knowledge transfer (KT) and knowledge application (KA). KT scale consists of 10 items and KA scale consists of 12 items (see Appendix 1). After cleaning the data, KT scale includes 7 items and KA scale includes 9 items.

To measure knowledge storage/retrieval (KSR), we use Chou et als (2007) scale, which consists of 4 items and measures organizational memory. Organizational memory refers to the processing of saved knowledge, a concept that coincides with our understanding of KSR (see Appendix 1). The final cleaned scale retains the 4 items.

In the case of the value creation, and after a review of the scales developed in previous investigations, we chose Hooley et als (2005) scale. The lack of proposals for 
measuring customer value creation created problems for the authors when seeking the most appropriate instrument for this construct. The model uses Hooley et a/s (2005) scale because this scale is complete and refers to the creation of value for customers (see Appendix 1).

Using Tuominen's (2004) scale as our basis, we developed a list of variables to help us measure the firm's value capture. Data was collected from each bank regarding market share; sales volume; overall profit levels; ROI (return on investment); and profit margins. This data was taken from the 2009 annual accounts of each bank posted on its website or from the website of the National Share Market Commission. Finally, data from benefits were used in the analysis (PROFIT1 and PROFIT2).

Data Analysis

The hypotheses 1 and 2, were tested simultaneously using partial least squares (PLS), a variance-based structural equation modeling (SEM) technique employing a principal component-based estimation approach (Chin, 1998). PLS was selected due to the characteristics of our model and sample. As the model uses reflective and formative indicators and the data is non-normal, other software packages for structural equation modeling (e.g., LISREL or AMOS) were inappropriate (Diamantopoulos \& Winklhofer, 2001).

Using PLS involves a two-stage approach (Barclay et al, 1995). The first step requires the assessment of the measurement model. This allows the relationships between the observable variables and theoretical concepts to be specified. This analysis is performed in relation to the attributes of individual item reliability, construct reliability, average variance extracted (AVE), and discriminant validity of the indicators of latent variables. For the second step, the structural model is evaluated. The objective of this is to confirm the extent to which the causal relationships specified by the proposed model are consistent with the available data.

To analyze the relationships between the different constructs and their indicators, we have adopted the latent model perspective, in which the latent variable is understood to be the cause of the indicators and, therefore, we refer to reflective indicators for firstorder constructs or dimensions. There are two reflective constructs in the model, while one construct (KM processes) is modeled as a high-order formative construct formed by a third-order construct named as KCREATION, and three first-order constructs: KTRANSFER, KAPPLICATION and KSTORAGE/RETRIEVAL. 
With regard to the measurement model, we began by assessing the individual item reliability (Table 1). The indicators exceed the accepted threshold of 0.707 for each factor loading (Carmines \& Zeller, 1979).

\section{Insert Table 1 about here}

From an examination of the results shown in Table 2, we can state that all of the constructs are reliable. The values for both the Cronbach's alpha coefficient and composite reliability are greater than the 0.7 (Nunnally, 1978). The AVE should be greater than 0.5 , meaning that $50 \%$ or more variance of the indicators should be accounted for (Fornell \& Larcker, 1981). All the constructs of our model exceed this condition (Table 2). To assess the discriminant validity, we compared the square root of the AVE (the diagonals in Table 2) with the correlations between constructs (the offdiagonal elements in Table 2). On average, each construct relates more strongly to its own measures than to others.

\section{Insert Table 2 about here}

The formative dimensions of the high-order construct, KM processes, are evaluated differently from reflective ones. We need to examine the weights (Mathieson et al, 2001), which is a canonical correlation analysis and provides information about how each indicator contributes to its respective construct (see Table 3).

\section{Insert Table 3 about here}

\section{Results}

Consistent with Hair et al (2011), a bootstrap test (5000 resamples) was used to generate standard errors and t-statistics. This enabled us to assess the statistical significance of the path coefficients. Table 4 sets out the model statistics, the path coefficients and the $t$ values observed with the level of significance obtained from the bootstrap test.

\section{Insert Table 4 about here}

The results shown in Table 4 support our hypotheses. First, a positive relationship exist between KM processes and value creation $(\beta=0.437, p<0.001)$. Second, a positive relationship exist between value creation and value capture $(\beta=0.128, p<0.001)$.

As we have stated before, the aim of this paper is not only to support $\mathrm{H} 1$ and $\mathrm{H} 2$. This study has also investigated how each knowledge process contributes to value creation. 
Value creation will increase if the firm carries out the four key KM processes proposed taking into account the importance of each of them.

Based on Table 3, we state that $\mathrm{KC}$ is the knowledge process that has more importance in value creation. The second knowledge process according to its importance in value creation would be KSR. And, the third one would be KA. Surprisingly, KT has no importance at all in value creation.

\section{Discussion}

The KBV provides insight into why firms exist (and will continue to exist) and, thus why organizing knowledge is a critical part of what firms do (Brown \& Duguid, 1998). If firms want to take advantage of the knowledge they possess, firms have to know how knowledge is created, shared and used in the firm (Ipe, 2003; Schiuma et al, 2012).

As Käpylä et al (2011) stated, the results indicate that KC should be considered in first place when firms want to create value for their customers. A possible explanation for this finding may relate to the fact that, in our study, $\mathrm{KC}$ is closely related to the 'absorptive capacity' concept. In other words, when firms look for new ways to create value for the customers, they need to recognize the value of new external information, assimilate it and apply it to commercial ends (Cohen \& Levinthal, 1990).

These data further indicate that, although KT is an important process for an effective $\mathrm{KM}$ in a firm, it has no influence in the creation of value for customers.

Referring to firm value capabilities, it would seem that neither value creation nor value capture should be considered separately. Both value creation and value capture capabilities are required for securing a competitive market position and achieving superior performance (Han et al, 1998). According to Mizik \& Jacobson (2003), value creation influences the potential magnitude of the firm's competitive advantage, while value capture influences the amount of the advantage the firm is able to capture and the duration of that advantage.

According to Mocciaro \& Battista (2005), the firm is not considered to be oriented exclusively towards either value creation or value capture, but rather both conditions characterize the process of firm development. Along the same line, Tuominen (2004) views value creation as an organizational capability that, along with the value capture capability, is necessary to achieve a competitive advantage in the marketplace. The superiority of firms that lead the competition cannot be based solely on the creation of 
value; they also have to be able to capture the value created through market share and profits (Mizik \& Jacobson, 2003; Tuominen, 2004).

\section{Conclusions}

Firms increasingly see knowledge as a strategic resource that can be harnessed and managed effectively to achieve competitive advantage and to survive (Snowden, 2003). Knowledge is also seen as the principal driver for the creation of value (Firestone \& McElroy, 2003; Qureshi et al, 2006; Moustaghfir, 2009).

In this context, KM is perceived as a framework for designing a firm's goals, structures and processes so that the firm can use its knowledge to learn and create value for its customers (Vorakulpipat \& Rezgui, 2008; Carlucci, 2012). Taking the previous arguments as our starting point, we state that one of the objectives of KM processes is value creation. A firm that manages its knowledge does so with the aim of increasing the value created for its customers.

Our paper shows how KM processes can be used for firms to create value and to capture the value created. In testing our research hypotheses, we test how a firm could create value for the customer, and how this value could be captured in the Spanish banking industry.

On the one hand, value creation involves the development of a set of capabilities related to the creation and renovation of the routes to competitive advantage. On the other hand, value capture involves the development of a set of capabilities oriented to the extraction of benefits derived from value creation. In other words, it focuses on the capture of market rents generated from the possession of specific differential resources or capabilities (Mocciaro \& Battista, 2005). For the capture of benefits to take place, isolating mechanisms that restrict competitive forces must be in place, since without them, there will be no incentives to create value for the customer (Mizik \& Jacobson, 2003).

Managerial Implications

$\mathrm{KM}$ processes are important topics in $\mathrm{KM}$ investigations, and they therefore require a great deal of analysis, especially with regard to empirical studies (Firestone \& McElroy, 2003). We believe that our paper responds to the demand for research in this knowledge area and the results of our study can also help firms to adjust their current $\mathrm{KM}$ in order to create and capture superior customer value (Mckenzie, 2008). 
First, our findings show to firms what KM processes should use to increase customer value. It is not enough for firms to possess the KM processes. According to our findings, we propose that KM processes have to be transformed into something that is of value to firms and customers. For example, there is little point in training intelligence competitive to create new knowledge for employees if they then fail to transfer their knowledge to make good strategy. Managers have to be aware of the value of the KM processes. Then, managers should train the employees in each of the KM processes or they should improve relationships between employees for sharing the knowledge that they each possess.

Secondly, our aim is to give guidance to firm managers about how they have to make decisions regarding value creation and value capture. Managers must understand how to manage KM processes to capture higher customer value. First of all, managers should establish a culture to foster the communication between employees to allow that departmental objectives to be aligned with firm objectives. Then they have to improve organizational effectiveness and efficiency through the improvement of creating new knowledge from the environment, transferring knowledge throughout organization, establishing an useful knowledge store for the entire workforce, and applying the output retrieved from this store to maximize customer value creation. It will help them to reconfigure and refine continually the pool of firm's KM processes.

Radical changes are being made in the financial sector, and more specifically in the banking industry, with banks facing difficult challenges in trying to overcome the crisis affecting the industry. We believe that the results of our study will encourage firms to reconsider the role of $\mathrm{KM}$ processes in their organizations, and take advantage of them to increase customer value.

The crisis in the industry has created an excellent opportunity for this study; that is, the circumstances of the financial environment (e.g., company mergers) provide the ideal framework in which to analyze the processes of KM that a firm should possess in order to face the organizational and cultural changes brought about in the process of condensing several companies into one. Providing managers in the current economic situation with the tools and capabilities to foster KM processes will help them to improve organizational effectiveness and efficiency.

This study has some limitations. First, results offer only a snapshot of current processes instead of measures of the same process over time. Second, although drawing on relevant, useable scales from the literature guarantees that the constructs' definition is as precise as possible, the constructs can credibly act only as proxies for 
an underlying latent phenomenon which is itself only partially measurable. Third, the model in this study is general and fails to capture the possible moderating effects of environmental turbulence and uncertainty. Prior research shows that the effect of cognitive factors on individual, group, and organizational performance can vary substantially with environmental conditions. Fourth, the cross-sectional (rather than longitudinal) design of the study might misrepresent variables that refer to lengthy processes, the effects of which only become apparent over long periods. Finally, the state of the industry, Spanish banking industry, at the time of the study is very important. Although this situation created an ideal opportunity for study, problems arose when collecting data for the empirical investigation. Because of the high degree of turbulence in the industry at that time and the fact that the industry and its problems and uncertainties were under considerable discussion, some managers were wary of giving out data. For this reason, researchers must be careful about generalizing these results and conclusions to other scenarios or different contexts

This investigation provides a springboard for future research into the maintenance or creation of value in the current environment, where competition is growing and the customer is becoming more demanding by the day. Possible future studies might extend the timescale and the scope of the study into other economic industries. Researchers would then be able to generalize the results and an extended model might include, for example, firms' other processes of KM and its diverse configurations that influence value creation and capture.

\section{References}

Alavi M and Leidner DE (2001) Review: knowledge management and knowledge management systems: conceptual foundations and research issues. MIS Quarterly 25(1), 107-136.

Barclay D, Higgins C and Thompson R (1995) The partial least squares (PLS) approach to causal modelling: personal computer adoption and use as an illustration. Technological Studies 2, 285-309.

Baskerville R and Dulipovici A (2006) The theoretical foundations of knowledge management. Knowledge Management Research \& Practice 4(2), 83-105.

Becerra-Fernandez I and Sabherwal R (2001) Organizational knowledge management: a contingency perspective. Journal of Management Information Systems 18(1), 23-55.

Brown JS and Duguid P (1998) Organizing knowledge. California Management Review 40(3), 90-111.

Carlucci D (2012) Assessing the links between knowledge assets and value creation in organisations. Measuring Business Excellence 16(2), 70-82. 
Carlucci D, Marr B and Schiuma G (2004) The knowledge value chain: how intellectual capital impacts on business performance. International Journal of Technology Management 27(6/7), 575-590.

Carmines EG and Zeller RA (1979) Reliability and Validity Assessment. Sage, London.

Chang Lee K, Lee S and Kang IW (2005) KMPI: measuring knowledge management performance. Information \& Management 42(3), 469-482.

Chen C-J and Huang J-W (2009) Strategic human resource practices and innovation performance - the mediating role of knowledge management capacity. Journal of Business Research 62(1), 104-114.

Chin WW (1998) Issues and opinion on structural equation modeling. MIS Quarterly 22(1), 1-12.

Chou S-W (2005) Knowledge creation: absorptive capacity, organizational mechanisms, and knowledge storage/retrieval capabilities. Journal of Information Science 31(6), 453-465.

Chou T-C, Chang P-L, Cheng Y-P and Tsai C-T (2007) A path model linking organizational knowledge attributes, information processing capabilities, and perceived usability. Information \& Management 44(4), 408-417.

Cohen WM and Levinthal DA (1990) Absorptive capacity: a new perspective on learning and innovation. Administrative Science Quarterly 35(1), 128-152.

Davenport TH and Prusak L (1998) Working Knowledge. Harvard Business School Press, Boston, MA.

De Vries RE, Van den Hooff B and De Ridder JA (2006) Explaining knowledge sharing: the role of team communication styles, job satisfaction, and performance beliefs. Communication Research 33(2), 115-135.

Denford JS and Chan YE (2011) Knowledge strategy typologies: defining dimensions and relationships. Knowledge Management Research \& Practice 9(2), 102-119.

Diamantopoulos A and Winklhofer H (2001) Index construction with formative indicators: an alternative to scale development. Journal of Marketing Research 38(2), 269-277.

Firestone JM and McElroy MW (2003) Key Issues In the New Knowledge Management. Butterworth-Heinemann, Waltham, MA.

Fornell C and Larcker DF (1981) Evaluating structural equation models with unobservable variables and measurement error. Journal of Marketing Research XXVII, 39-50.

Gebert H, Geib M, Kolbe L and Brenner W (2003) Knowledge-enabled customer relationship management: integrating customer relationship management and knowledge management concepts[1]. Journal of Knowledge Management, 7(5), 107-123.

Gold AH, Malhotra A and Segars AH (2001) Knowledge management: an organizational capabilities perspective. Journal of Management Information Systems 18(1), 185-214.

Hair JF, Ringle C and Sarstedt M (2011) PLS-SEM: indeed a silver bullet. Journal of Marketing Theory and Practice 19(2), 139-152.

Han JK, Kim N and Srivastava RK (1998) Market orientation and organizational performance: is innovation a missing link? Journal of Marketing 62(4), 30-45. 
Holsapple CW and Wu J (2008) In search of a missing link. Knowledge Management Research \& Practice 6(1), 31-40.

Hooley GJ, Greenley GE, Cadogan JW and Fahy J (2005) The performance impact of marketing resources. Journal of Business Research 58(1), 18-27.

Ipe M (2003) Knowledge sharing on organizations: a conceptual framework. Human Resource Development Review 2(4), 337-359.

Jansen JJP, Van den Bosch FAJ and Volberda HW (2005) Managing potential and realized absorptive capacity: how do organizational antecedents matter? Academy of Management Journal 48(6), 999-1015.

Jantunen A (2005) Knowledge-processing capabilities and innovative performance: an empirical study. European Journal of Innovation Management 8(3), 336-349.

Käpylä J, Laihonen H, Lönnqvist A and Carlucci D (2011) Knowledge-intensity as an organisational characteristic. Knowledge Management Research \& Practice 9(4), 315-326.

Kiessling TS, Richey RG, Meng J and Dabic M (2009) Exploring knowledge management to organizational performance outcomes in a transitional economy. Journal of World Business 44(4), 421-433.

Lane PJ, Koka BR and Pathak S (2006) The reification of absorptive capacity: a critical review and rejuvenation of the construct. Academy of Management Review 31(4), 833-863.

Lee D-J and Ahn J-H (2007) Reward systems for intra-organizational knowledge sharing. European Journal of Operational Research 180(2), 938-956.

Lin H-F and Lee G-G (2005) Impact of organizational learning and knowledge management factors on e-business adoption. Management Decision 43(2), 171-188.

Malhotra NK and Birks DF (2006) Marketing Research, an Applied Approach, Updated Secondary European Edition. Pearson Education, Harlow, UK.

Marr B, Schiuma G and Neely A (2004) The dynamics of value creation: mapping your intellectual performance drivers. Journal of Intellectual Capital 5(2), 312-325.

Mathieson K, Peacock E and Chin WW (2001) Extending the technology acceptance model: the influence of perceived user resources. The Data Base for Advances in Information Systems 32, 86-112.

McElroy MW (2000) Integrating complexity theory, knowledge management and organizational learning. Journal of Knowledge Management 4(3), 195-203.

Mckenzie B (2008) Customer relationship management and customer recovery and retention: the case of the 407 express toll route. Knowledge Management Research \& Practice 6(2), 155-163.

Mizik N and Jacobson R (2003) Trading off between value creation and value appropriation: the financial implications of shifts in strategic emphasis. Journal of Marketing 67(1), 63-76.

Mocciaro A and Battista G (2005) The development of the resource-based firm between value appropriation and value creation. Advances in Strategic Management 22, 153-188. 
Moustaghfir K (2009) How knowledge assets lead to a sustainable competitive advantage: are organizational capabilities a missing link? Knowledge Management Research \& Practice 7(4), 339-355.

Newey LR and Zahra SA (2009) The evolving firm: how dynamic and operating capabilities interact to enable entrepreneurship. British Journal of Management 20, S81-S100.

Nilakanta S, Miller LL and Zhu D (2006) Organizational memory management: technological and research issues. Journal of Database Management 17(1), 85-94.

Nonaka I and Toyama R (2002) A firm as a dialectical being: towards a dynamic theory of a firm. Industrial \& Corporate Change 11(5), 995-1009.

Nunnally JC (1978) Psychometric theory. McGraw-Hill, New York, NY.

Payne A and Holt S (2001) Diagnosing customer value: integrating the value process and relationship marketing. British Journal of Management 12(2), 159-182.

Qureshi S, Briggs RO and Hlupic V (2006) Value creation from intellectual capital: convergence of knowledge management and collaboration in the intellectual bandwidht model. Group Decision and Negotiation 15, 197-220.

Radaelli G, Mura M, Spiller N and Lettieri E (2011) Intellectual capital and knowledge sharing: the mediating role of organisational knowledge-sharing climate. Knowledge Management Research \& Practice 9(4), 342-352.

Rezgui Y (2007) Knowledge systems and value creation. Industrial Management \& Data Systems 107(2), 166-182.

Sanchez R, Iniesta MA and Holbrook MB (2009) The conceptualisation and measurement of consumer value in services. International Journal of Market Research 51(1), 93-113.

Sanchez R and Iniesta MA (2006) Consumer perception of value: literature review and a new conceptual framework. Journal of Consumer Satisfaction, Dissatisfaction and Complaining Behavior 19, 40-48.

Schiuma G (2009) The managerial foundations of knowledge assets dynamics. Knowledge Management Research \& Practice 7(4), 290-299.

Schiuma G, Carlucci D and Lerro A (2012) Managing knowledge processes for value creation. VINE 42(1), 4-14.

Slater SF (1997) Developing a customer value-based theory of the firm. Journal of the Academy of Marketing Science 25(2), 162-167.

Slater SF and Narver JC (1998) Customer-led and market-oriented: let's not confuse the two. Strategic Management Journal 19(10), 1001-1006.

Snowden D (2003) The knowledge you need, right when you need it. Knowledge Management Review 5(6), 24-27.

Teece DJ, Pisano G and Shuen A (1997) Dynamic capabilities and strategic management. Strategic Management Journal 18(7), 509-533.

Tuominen M (2004) Channel collaboration and firm value proposition. International Journal of Retail \& Distribution Management 32(4), 178-189. 
Ulaga W (2001) Customer value in business markets: an agenda for inquiry. Industrial Marketing Management 30(4), 315-319.

Venkataraman S and Sarasvathy SD (2001) Strategy and Entrepreneurship. In Handbook of Strategic Management (Hitt MA, Freeman RE and Harrison JS, Eds.), pp 650-668, Blackwell, Oxford.

Vorakulpipat C and Rezgui Y (2008) Value creation: the future of knowledge management. The Knowledge Engineering Review 23(3), 283-294.

Wales WJ, Parida V and Patel PC (2013) Too much of a good thing? Absorptive capacity, firm performance, and the moderating role of entrepreneurial orientation. Strategic Management Journal 34(5), 622-633.

Walsh JP and Ungson GR (1991) Organizational memory. Academy of Management Review 16(1), 57-91.

Wiig KM (2007) Effective societal knowledge management. Journal of Knowledge Management 11(5), 141-156.

Woodall T (2003) Conceptualising 'value for the customer': an attributional, structural and dispositional analysis. Academy of Marketing Science Review 2003, 1-42.

Woodruff RB (1997) Customer value: the next source for competitive advantage. Journal of the Academy of Marketing Science 25(2), 139-153.

Zahra SA and George G (2002) Absorptive capacity: a review, reconceptualization, and extension. Academy of Management Review 27(2), 185-203. 


\section{Appendix 1. Questionnaire items}

\section{PACAP}

Acquisition

ACQ_1: Our unit has frequent interactions with corporate headquarters to acquire new knowledge.

ACQ_2: Employees of our unit regularly visit other branches.

ACQ_3: We collect industry information through informal means (e.g., lunch with industry friends, talks with trade partners).

ACQ_4: Other divisions of our company are hardly visited (reverse-coded).

ACQ_5: Our unit periodically organizes special meetings with customers or third parties to acquire new knowledge.

ACQ_6: Employees regularly approach third parties such as accountants, consultants, or tax consultants.

Assimilation

ASS_1: We are slow to recognize shifts in our market (e.g., competition, regulation, demography) (reverse-coded)

ASS_2: Ne opportunities to serve our clients are quickly understood.

ASS_3: We quickly analyze and interpret changing market demands.

RACAP

Transformation

TRA_1: Our unit regularly considers the consequences of changing market demands in terms of new products and services.

TRA_2: Employees record and store newly acquired knowledge for future reference.

TRA_3: Our unit quickly recognizes the usefulness of new external knowledge to existing knowledge.

TRA_4: Employees hardly share practical experiences (reverse-coded)

TRA_5: We laboriously grasp the opportunities for our unit from new external knowledge (reverse-coded).

TRA_6: Our unit periodically meets to discuss consequences of market trends and new product development.

\section{Exploitation}


EXP_1: It is clearly known how activities within our unit should be performed.

EXP_2: Client complaints fall on deaf ears in our unit (reverse-coded).

EXP_3: Our unit has a clear division of roles and responsibilities.

EXP_4: We constantly consider how to better exploit knowledge.

EXP_5: Our unit has difficulty implementing new products and services (reversecoded).

EXP_6: Employees have a common language regarding our products and services.

Knowledge transfer

My organization has processes for:

$\mathrm{KT}$ 1: converting knowledge into the design of new services

KT_2: converting competitive intelligence into plans of action

KT_3: filtering knowledge

KT_4: transferring organizational knowledge to individuals

KT_5: absorbing knowledge from individuals into the organization

KT_6: absorbing knowledge from business partners into the organization

KT_7: distributing knowledge throughout the organization

KT_8: integrating different sources and types of knowledge

KT_9: organizing knowledge

KT_10: replacing outdated knowledge

Knowledge storage and retrieval

KSR_1: Organizational conversation keeps the lessons learned from service development history at the front of our minds

KSR_2: We always audit unsuccessful service development endeavors and communicate the lessons learned

KSR_3: We have specific mechanisms for sharing lessons learned in the service development process

KSR_4: Formal routines exist to uncover faulty assumptions about the service development process

Knowledge application.

KA_1: My organization has processes for applying knowledge learned from mistakes KA_2: My organization has processes for applying knowledge learned from experiences 
KA_3: My organization has processes for using knowledge in the development of new services

KA_4: My organization has processes for using knowledge to solve problems

KA_5: My organization matches sources of knowledge to problems and challenges

KA_6: My organization uses knowledge to improve efficiency

KA_7: My organization uses knowledge to adjust strategic direction

KA_8: My organization is able to locate and apply knowledge to changing competitive conditions

KA_9: My organization makes knowledge accessible to those who need it

KA_10: My organization takes advantage of new knowledge

KA_11: My organization quickly applies knowledge to critical competitive needs

KA_12: My organization quickly links sources of knowledge in solving problems

Customer value creation.

CV_1: Levels of customer loyalty compared to competitors

CV_2: Levels of customer satisfaction compared to last year

CV_3: Levels of customer loyalty compared to last year 
Table 1: Factor loadings for the measurement model

\begin{tabular}{|c|c|c|c|c|c|c|c|c|c|}
\hline & ACQUISITION & ASSIMILATION & TRANSFORMATION & EXPLOITATION & KTRANSFER & KAPPLICATION & $\begin{array}{l}\text { KSTORAGE/ } \\
\text { RETRIEVAL }\end{array}$ & $\begin{array}{c}\text { VALUE } \\
\text { CREATION }\end{array}$ & VALUE CAPTURE \\
\hline ACQ1 & 0,8095 & 0,4212 & 0,5781 & 0,5391 & 0,6584 & 0,6743 & 0,4868 & 0,3911 & 0,1085 \\
\hline ACQ2 & 0,6959 & 0,193 & 0,4735 & 0,2901 & 0,3655 & 0,3447 & 0,2973 & 0,1332 & $-0,052$ \\
\hline ACQ3 & 0,7485 & 0,1132 & 0,4798 & 0,3423 & 0,3893 & 0,3953 & 0,2765 & 0,0187 & $-0,0632$ \\
\hline ACQ4 & 0,7258 & 0,3302 & 0,4947 & 0,5334 & 0,4971 & 0,4209 & 0,4129 & 0,2175 & $-0,1011$ \\
\hline ACQ5 & 0,6993 & 0,231 & 0,5033 & 0,3842 & 0,4567 & 0,4383 & 0,3454 & 0,0872 & $-0,0349$ \\
\hline ASS1 & 0,3194 & 0,79 & 0,4453 & 0,33 & 0,4468 & 0,4876 & 0,5121 & 0,3413 & 0,073 \\
\hline ASS2 & 0,4743 & 0,9046 & 0,6232 & 0,6749 & 0,6579 & 0,633 & 0,6402 & 0,3664 & $-0,025$ \\
\hline ASS3 & 0,3128 & 0,9096 & 0,5776 & 0,5201 & 0,5276 & 0,5172 & 0,5501 & 0,3082 & 0,0728 \\
\hline TRA1 & 0,5697 & 0,499 & 0,7549 & 0,5073 & 0,6744 & 0,6319 & 0,5641 & 0,2639 & 0,1379 \\
\hline TRA2 & 0,4423 & 0,3802 & 0,7226 & 0,5385 & 0,4982 & 0,4776 & 0,4936 & 0,1227 & $-0,063$ \\
\hline TRA3 & 0,5357 & 0,5793 & 0,7994 & 0,5263 & 0,5546 & 0,5823 & 0,6719 & 0,2751 & $-0,086$ \\
\hline TRA6 & 0,5266 & 0,4419 & 0,7087 & 0,5771 & 0,4845 & 0,523 & 0,5587 & 0,1484 & $-0,1736$ \\
\hline EXP1 & 0,5086 & 0,5123 & 0,6028 & 0,8364 & 0,5851 & 0,5788 & 0,6285 & 0,39 & $-0,1812$ \\
\hline EXP4 & 0,4451 & 0,4753 & 0,6185 & 0,8493 & 0,718 & 0,5092 & 0,7158 & 0,2301 & $-0,1201$ \\
\hline EXP5 & 0,4213 & 0,4747 & 0,5305 & 0,7225 & 0,5066 & 0,4935 & 0,5468 & 0,2448 & $-0,1624$ \\
\hline EXP6 & 0,4657 & 0,4001 & 0,4985 & 0,7124 & 0,4579 & 0,4662 & 0,4364 & 0,3035 & 0,0981 \\
\hline KT1 & 0,5168 & 0,5641 & 0,7093 & 0,6694 & 0,8194 & 0,7472 & 0,6589 & 0,3105 & 0,0983 \\
\hline KT2 & 0,5165 & 0,5398 & 0,6373 & 0,5601 & 0,857 & 0,7522 & 0,5941 & 0,4243 & 0,0724 \\
\hline КТ3 & 0,5482 & 0,5482 & 0,6333 & 0,6777 & 0,8837 & 0,7236 & 0,6158 & 0,3451 & 0,0922 \\
\hline KT4 & 0,5097 & 0,4609 & 0,479 & 0,5686 & 0,7924 & 0,7271 & 0,5336 & 0,3743 & 0,1107 \\
\hline КT7 & 0,5372 & 0,5181 & 0,5464 & 0,6105 & 0,8128 & 0,6769 & 0,5785 & 0,3859 & 0,1471 \\
\hline КT8 & 0,4751 & 0,5305 & 0,5254 & 0,5405 & 0,807 & 0,724 & 0,6188 & 0,3246 & 0,1598 \\
\hline КТ9 & 0,5964 & 0,5129 & 0,6411 & 0,5381 & 0,8596 & 0,702 & 0,5737 & 0,1855 & 0,0307 \\
\hline KA1 & 0,4199 & 0,3787 & 0,5338 & 0,5303 & 0,5832 & 0,7602 & 0,5169 & 0,2289 & 0,064 \\
\hline KA2 & 0,4915 & 0,5643 & 0,6211 & 0,583 & 0,707 & 0,8441 & 0,5798 & 0,3158 & 0,0617 \\
\hline KA3 & 0,594 & 0,6023 & 0,6913 & 0,6518 & 0,703 & 0,8917 & 0,6483 & 0,336 & 0,0767 \\
\hline KA4 & 0,601 & 0,6948 & 0,6877 & 0,6435 & 0,7065 & 0,8721 & 0,7045 & 0,347 & 0,0983 \\
\hline KA5 & 0,4344 & 0,5301 & 0,5244 & 0,6514 & 0,6952 & 0,7775 & 0,5875 & 0,2531 & 0,0676 \\
\hline KAG & 0,6133 & 0,3843 & 0,5704 & 0,5729 & 0,7091 & 0,8035 & 0,5815 & 0,3034 & $-0,0201$ \\
\hline KA7 & 0,598 & 0,4616 & 0,5667 & 0,4739 & 0,6848 & 0,776 & 0,6044 & 0,3366 & 0,081 \\
\hline KA10 & 0,5126 & 0,5068 & 0,5507 & 0,6502 & 0,7444 & 0,842 & 0,6969 & 0,3599 & 0,0263 \\
\hline KA11 & 0,5487 & 0,5334 & 0,6301 & 0,6519 & 0,7165 & 0,8226 & 0,6963 & 0,2859 & $-0,0838$ \\
\hline KSR1 & 0,491 & 0,6568 & 0,6986 & 0,6708 & 0,7148 & 0,6882 & 0,8565 & 0,4084 & 0,0132 \\
\hline KSR2 & 0,4126 & 0,5132 & 0,614 & 0,6623 & 0,5664 & 0,6183 & 0,8625 & 0,3651 & $-0,1489$ \\
\hline KSR3 & 0,5183 & 0,5254 & 0,6059 & 0,6 & 0,6316 & 0,6876 & 0,8576 & 0,29 & $-0,1166$ \\
\hline KSR4 & 0,3657 & 0,5356 & 0,6187 & 0,6406 & 0,5749 & 0,6428 & 0,8644 & 0,3087 & $-0,1511$ \\
\hline vC1 & 0,2396 & 0,3812 & 0,2826 & 0,3024 & 0,3587 & 0,344 & 0,3846 & 0,823 & 0,1423 \\
\hline VC2 & 0,2834 & 0,2705 & 0,1668 & 0,338 & 0,352 & 0,3532 & 0,3224 & 0,8447 & 0,0673 \\
\hline VC3 & 0,2019 & 0,3349 & 0,2313 & 0,3171 & 0,3398 & 0,3236 & 0,3276 & 0,8987 & 0,1156 \\
\hline PROFIT1 & $-0,0132$ & 0,0727 & $-0,0401$ & $-0,1002$ & 0,1238 & 0,0655 & $-0,0636$ & 0,1313 & 0,9831 \\
\hline PROFIT2 & 0,0071 & 0,0093 & $-0,0928$ & $-0,1452$ & 0,0604 & 0,0272 & $-0,1549$ & 0,1226 & 0,9806 \\
\hline
\end{tabular}


Table 2: Descriptive statistics and correlation matrix

\begin{tabular}{lccccccccccc}
\hline & Mean $^{\mathrm{a}}$ & SD & CA & CR & AVE & 1 & 2 & 3 & 4 & 5 & 6 \\
\hline 1. KCREATION & 5.29 & 1.16 & n.a & n.a & n.a & n.a & & & & \\
2. KTRANSFER & 5.38 & 1.14 & 0.94 & 0.94 & 0,70 & 0.81 & $\mathbf{0 . 8 4}$ & & & \\
3. KAPPLICATION & 5.47 & 1.09 & 0.93 & 0.95 & 0.69 & 0.80 & 0.77 & $\mathbf{0 . 8 3}$ & & \\
4. KSTORAGE/RETRIEVAL & 5.16 & 1.12 & 0.88 & 0.92 & 0.74 & 0.79 & 0.81 & 0.76 & $\mathbf{0 . 8 6}$ & & \\
5. VALUE CREATION & 5.24 & 1.21 & 0.89 & 0.81 & 0.73 & 0.42 & 0.37 & 0.39 & 0.40 & $\mathbf{0 . 8 5}$ & \\
6. VALUE CAPTURE & 0 & 1 & 0.98 & 0.96 & 0.96 & -0.04 & 0.07 & 0.04 & -0.11 & 0.12 & $\mathbf{0 . 9 8}$ \\
\hline
\end{tabular}

Notes:

Mean $=$ the average score for all of the items included in this measure; SD. = Standard Deviation; CA = Cronbach's Alpha; $\mathrm{CR}=$

Composite Reliability; $\mathrm{AVE}=$ Average Variance Extracted; n.a. = not applicable. The bold numbers on the diagonal are the square root of

the Average Variance Extracted. Off-diagonal elements are correlations among constructs.

Table 3: Weights of formative constructs

\begin{tabular}{lcc}
\hline \multicolumn{1}{c}{ High-order constructs and their dimensions (level) } & weights & t-values ${ }^{\mathrm{a}}$ \\
\hline KNOWLEDGE MANAGEMENT PROCESSES (higher-order) & & \\
KCREATION (third-order) & $\mathbf{0 . 5 2}$ & $\mathbf{3 , 7 8}$ \\
Potential Absorptive Capacity (second-order) & 0.57 & 24.11 \\
Acquisition (first order) & 0.32 & 3.64 \\
Assimilation (first-order) & 0,82 & 14.00 \\
Realized Absorptive Capacity (second-order) & 0.51 & 21.66 \\
Transformation (first-order) & 0.1 & 0.71 \\
& & \\
Exploitation (first-order) & 0.93 & 8.96 \\
KTRANSFER & $\mathbf{0 . 0 1}$ & $\mathbf{0 . 0 1}$ \\
KAPPLICATION & $\mathbf{0 . 2 4}$ & $\mathbf{1 . 2 6}$ \\
KSTORAGE/RETRIEVAL & $\mathbf{0 . 3 2}$ & $\mathbf{2 . 4 3}$ \\
\hline a Factor correction applied. & & \\
\hline
\end{tabular}

${ }^{\mathrm{a}}$ Factor correction applied.

Table 4: Model statistics

\begin{tabular}{lccc}
\hline \multicolumn{1}{c}{ Hypotheses } & $\begin{array}{c}\text { Path } \\
\text { coefficients }\end{array}$ & t-values $^{\mathrm{a}}$ & $\mathrm{R}^{2}$ \\
\hline H1: KM Processes $\rightarrow$ Value Creation & $0.437^{* * *}$ & 15.21 & 0.19 \\
H2: Value Creation $\rightarrow$ Value Capture & $0.128^{* * *}$ & 4.69 & 0.02 \\
\hline
\end{tabular}

${ }^{* * *} \mathrm{p}<0.001, * * \mathrm{p}<0.01,{ }^{*} \mathrm{p}<0.05, \mathrm{~ns}$ : not significant (based on a Student $\mathrm{t}(4999)$, one-tailed test).

$\mathrm{t}(0.05,4999)=1.645158499, \mathrm{t}(0.01,4999)=2.327094067, \mathrm{t}(0.001,4999)=3.091863446$
${ }^{\mathrm{a}}$ Factor correction applied. 
Figure 1: Proposed Research Model

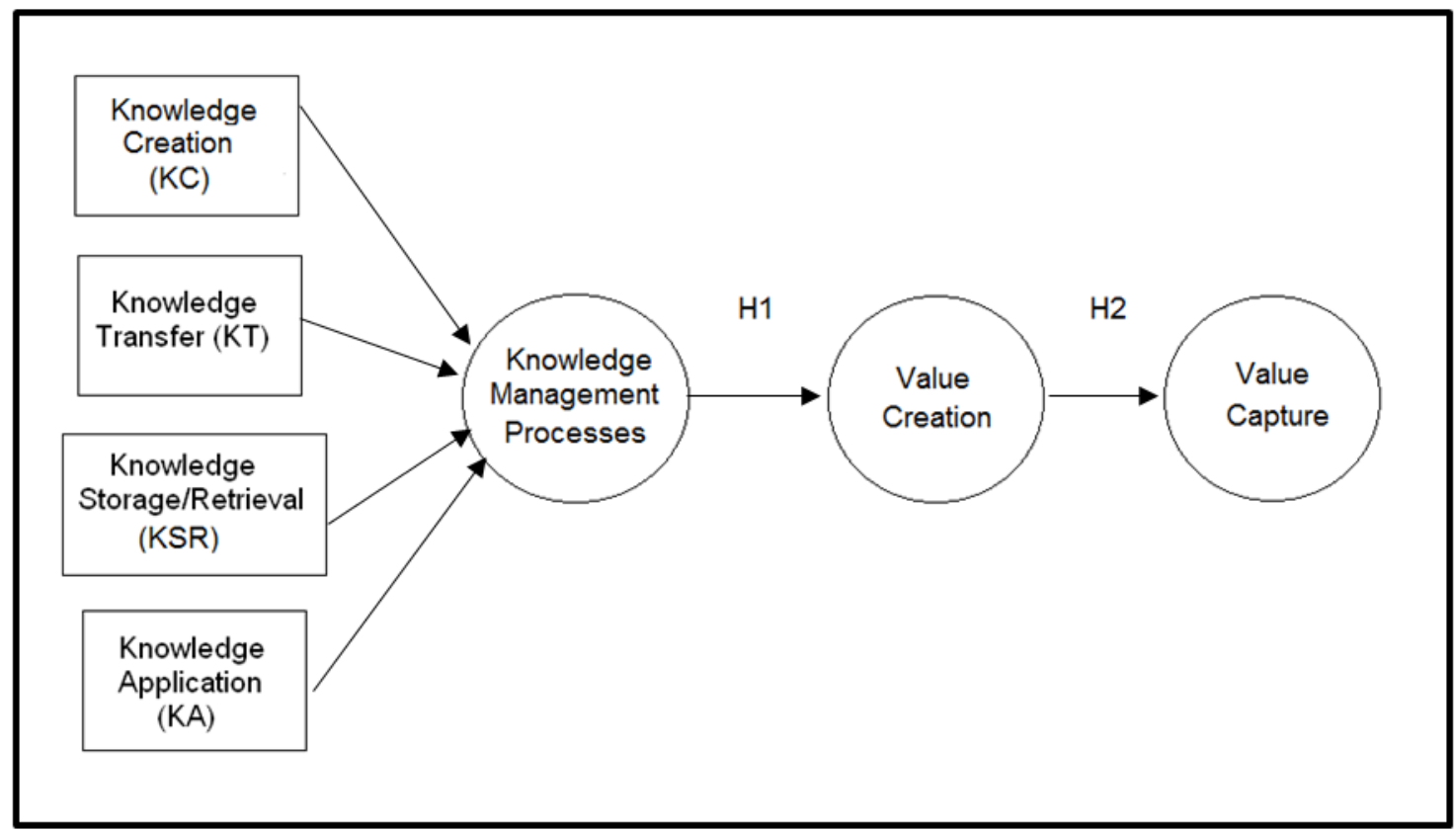

